\title{
Article \\ Purification and Characterization of WA18, a New Mycocin Produced by Wickerhamomyces anomalus Active in Wine Against Brettanomyces bruxellensis Spoilage Yeasts
}

\author{
Francesca Comitini *, Alice Agarbati, Laura Canonico, Edoardo Galli and Maurizio Ciani *(D) \\ Dipartimento di Scienze della Vita e dell'Ambiente (DiSVA), Università Politecnica delle Marche, \\ Via Brecce Bianche, 60131 Ancona, Italy; a.agarbati@pm.univpm.it (A.A.); 1.canonico@univpm.it (L.C.); \\ e.galli@pm.univpm.it (E.G.) \\ * Correspondence: f.comitini@univpm.it (F.C.); m.ciani@univpm.it (M.C.)
}

check for

updates

Citation: Comitini, F.; Agarbati, A.; Canonico, L.; Galli, E.; Ciani, M.

Purification and Characterization of WA18, a New Mycocin Produced by Wickerhamomyces anomalus Active in Wine Against Brettanomyces bruxellensis Spoilage Yeasts. Microorganisms 2021, 9, 56. https://doi.org/10.3390/ microorganisms 9010056

Received: 3 December 2020 Accepted: 24 December 2020 Published: 28 December 2020

Publisher's Note: MDPI stays neutral with regard to jurisdictional claims in published maps and institutional affiliations.

Copyright: () 2020 by the authors. Licensee MDPI, Basel, Switzerland. This article is an open access article distributed under the terms and conditions of the Creative Commons Attribution (CC BY) license (https: / / creativecommons.org/ licenses/by/4.0/).

\begin{abstract}
Wickerhamomyces anomalus strain 18, isolated from a natural underground cheese ripening pit, secretes a mycocin named WA18 that inhibits wine spoilage yeasts belonging to Brettanomyces bruxellensis species, with a broad-spectrum of activity. WA18 was purified, and the purified protein was digested with specific restriction enzymes (lysine K and arginine R cut sites). The LC-MS and LC-MS/MS analysis after enzymatic digestions revealed a molecular weight of $31 \mathrm{kDa}$. Bioinformatics processing and database research of digested pure killer protein showed $99 \%$ identity with a UDP-glycosyltransferase protein. Competitive inhibition assay of killer activity by cell-wall polysaccharides suggests that branched glucans represent the first receptor site of the toxin on the envelope of the sensitive target. The WA18 partially purified crude extract (PPCE) showed high stability of antimicrobial activity at the physicochemical conditions suitable for the winemaking process. Indeed, in wine WA18 was able to counteract B. bruxellensis and control the production of ethyl phenols. In addition, the strain WA18 was compatible with Saccharomyces cerevisiae in co-culture conditions with a potential application together with commercial starter cultures. These data suggest that WA18 mycocin is a promising biocontrol agent against spoilage yeasts in winemaking, particularly during wine storage.
\end{abstract}

Keywords: killer yeasts; killer toxin; Wickerhamomyces anomalus; spoilage yeasts; biocontrol; bioactive yeasts

\section{Introduction}

Yeast killer toxins are defined as antimicrobial proteinaceous compounds able to counteract sensitive yeast strains, although they remain immune to their own toxin effect [1]. Recently, killer yeasts and relative toxins have been reviewed by several authors discussing the molecular mode of action and their potential applications in view of possible use as preservatives in several fields [1-5].

The use of killer yeasts can be considered a promising strategy in the terrestrial primary production for the control of microbial decay [6,7]. Among them, the killer yeasts Kluyveromyces wickerhamii, Wickerhamomyces anomalus and Pichia membranifaciens represent an excellent example and have been extensively studied for their efficacy toward different sensitive spoilage yeasts in the winemaking field.

W. anomalus is an ascomycetous heterothallic yeast of the family Wickerhamomycetaceae that reproduces asexually by budding and sexually by the formation of hat-shaped ascospores [8]. Strains of this species are present in several environments and have been mainly isolated from fruits and plant materials, cereal grain, maize silage, high-sugar food products, and wine [8]. W. anomalus can grow under extreme environmental stress conditions, such as low and high $\mathrm{pH}$, low water activity, high osmotic pressure and anaerobic conditions [9]. W. anomalus is classified as a biosafety level 1 organism that 
is considered safe for healthy individuals, as reported in the online update of EFSA in March 2020 (https:/ / www.efsa.europa.eu/it/efsajournal/pub/6174). For this, in the last days, W. anomalus has been studied for its biocontrol property against spoilage yeasts, mainly Dekkera/Brettanomyces [10,11]. For example, W. anomalus NCYC 434 and its killer protein (panomycocin) has been suggested as a potential antifungal agent [12], while it was revealed that Pikt, a small size mycocin from $W$. anomalus, is able to reduce wine contamination in substitution to sulfur dioxide. More recently, de Ullivarri and coworkers [13] evaluated the killer strain $W$. anomalus Cf20 as a potential biocontrol agent active against a broad spectrum of wine yeasts, such as Pichia guilliermondii, P. membranifaciens, Brettanomyces bruxellensis and Dekkera anomala. Furthermore, W. anomalus strains have been extensively studied for applications against postharvest spoilage molds during table and or wine grape conservation [14,15]. Indeed, W. anomalus, similarly to other yeasts as Metschnikowia spp., produces a large spectrum of volatile low molecular weight compounds $<300$ Da (VOCs) characterized by low polarity and high vapor pressure that strongly inhibit the microbial growth [16,17].

The contaminations of Brettanomyces yeasts, the imperfect form of sporogenic Dekkera, are responsible for the loss of the fruity aromas of the wines and the formation of undesirable olfactory notes called "Brett character" as 4-ethyl phenol from the p-cumaric acid and 4 ethyl guaiacol from ferulic acid. These compounds have been identified as primarily responsible for the appearance of phenol and animal odors such as horse sweat, medicinal, leather, smoky, earthy, burnt plastic and solvent $[18,19]$. Based on the wide spectrum of action of the mycocins produced by $W$. anomalus and their strong efficacy towards sensitive yeasts, these toxins and the related producer strains are already applied in enology to control the fermentation process. For example, the mycocin KTCf20, produced by W. anomalus $\mathrm{Cf} 20$ strain, is a highly stable protein at $\mathrm{pH}$ values between 3.0 and 5.5 and temperature up to $37^{\circ} \mathrm{C}$ with a wide spectrum of action against spoilage yeasts and represent a potential antimicrobial tool in the cellar [13].

In this work, it was investigated W. anomalus strain 18 isolated and identified as a mycocin producer during a microbiological investigation on a typical Italian cheese ripened in a peculiar natural underground pit characterized by anoxygenic conditions and lowtemperature [20]. The mycocin named WA18 was purified, biochemically characterized, and preliminarily evaluated against B. bruxellensis strains under oenological conditions, monitoring the growth and the production of ethyl phenols in wine.

\section{Materials and Methods}

\subsection{Yeast Strains and Growth Media}

W. anomalus strain 18 was isolated and identified in previous work [20] during an isolation campaign of autochthonous yeasts in special underground pits of sandstone rock used to ripen a traditional Italian cheese. All sensitive yeast strains belonging to $B$. bruxellensis coming from the Yeast Collection of the Department of Life and Environmental Sciences (DiSVA) of the Polytechnic University of Marche (Italy). DiSVA potential sensitive strains were mainly isolated from vineyard or cellar environments (Table 1).

All strains were cultured in yeast peptone dextrose (YPD) broth containing $10 \mathrm{~g} \mathrm{~L}^{-1}$ yeast extract, $20 \mathrm{~g} \mathrm{~L}^{-1}$ peptone, $20 \mathrm{~g} \mathrm{~L}^{-1}$ glucose, $18 \mathrm{~g} \mathrm{~L}^{-1}$ agar. If required, for assays in liquid, the $\mathrm{pH}$ was buffered at 4.2 with $0.1 \mathrm{M}$ citric acid/dibasic sodium phosphate. For killer activity assay, Malt Agar (Biolife, Monza, Italia) supplemented with $30 \mathrm{mg} \mathrm{L}^{-1}$ methylene blue-buffered at $\mathrm{pH} 4.2$ was used. All strains were maintained in YPD supplemented with $20 \%$ glycerol at $-80{ }^{\circ} \mathrm{C}$. The medium used to produce WA18 was YPD-modified (type A) as following: dextrose $15 \mathrm{~g} \mathrm{~L}^{-1}$, yeast extract $10 \mathrm{~g} \mathrm{~L}^{-1}$, malt extract $5 \mathrm{~g} \mathrm{~L}^{-1}$, casein peptone $5 \mathrm{~g} \mathrm{~L}^{-1}$; buffered to $\mathrm{pH} 4.4$ with $0.1 \mathrm{M}$ citrate phosphate buffer.

Vinification trials were carried out using commercial sterile grape must name Folicello (www.folicello.it) supplemented with $10 \mathrm{mg} \mathrm{L}^{-1}$ p-cumaric acid as the main phenol's precursor. 
Table 1. List of Brettanomyces strains used and sources from which they were isolated. In the third column, the symbols report the killer effect of mycocin WA18 on the related sensitive strains. Legend: ++ strong killer action (diameter of halo $>15 \mathrm{~mm}$ ), + evident killer action (diameter of halo between 14 and $10 \mathrm{~mm}$ ), + / - weak killer action (diameter of halo $<10 \mathrm{~mm}$ and not persistent), - no killer action.

\begin{tabular}{|c|c|c|}
\hline Sensitive Yeast Codes & Isolation Source & Killer Activity \\
\hline Type strain DiSVA 46 & Beer & + \\
\hline 20 & Winery environments & ++ \\
\hline $21-\mathrm{A} 4$ & Winery environments & + \\
\hline 21-B1 & Winery environments & + \\
\hline $21-\mathrm{C} 2$ & Winery environments & + \\
\hline $25-\mathrm{A}$ & Winery environments & + \\
\hline $25-B$ & Winery environments & + \\
\hline $14-\mathrm{A}$ & Winery environments & + \\
\hline 14-B2 & Winery environments & + \\
\hline $14-\mathrm{C}$ & Winery environments & + \\
\hline $10-\mathrm{A}$ & Winery environments & + \\
\hline 10-A1 & Winery environments & - \\
\hline $10-B$ & Winery environments & + \\
\hline Disva 48 & Tea-beer & - \\
\hline $10-\mathrm{C}$ & Winery environments & - \\
\hline $5-6 \mathrm{~A}$ & Winery environments & + \\
\hline $5-6 \mathrm{~B}$ & Winery environments & + \\
\hline $5-6 \mathrm{C}$ & Winery environments & + \\
\hline $212-C$ & $\begin{array}{l}\text { Winery equipment } \\
\text { (connection valves) }\end{array}$ & + \\
\hline $212-\mathrm{D}$ & $\begin{array}{l}\text { Winery equipment } \\
\text { (connection valves) }\end{array}$ & + \\
\hline $219-\mathrm{A}$ & $\begin{array}{l}\text { Winery equipment } \\
\text { (connection valves) }\end{array}$ & + \\
\hline 1.M & Red wine (Montepulciano) & $+/-$ \\
\hline $4 . \mathrm{M}$ & Red wine (Montepulciano) & ++ \\
\hline $5 . \mathrm{M}$ & Red wine (Montepulciano) & $+/-$ \\
\hline $6 . \mathrm{M}$ & Red wine (Montepulciano) & - \\
\hline 11.M & Red wine (Montepulciano) & - \\
\hline 12.M & Red wine (Montepulciano) & $+/-$ \\
\hline Disva 79 & Grape must & ++ \\
\hline PSTA 11 & Wine & + \\
\hline EB1G & Montepulciano Wine & ++ \\
\hline EB1p & Montepulciano Wine & ++ \\
\hline 2.3 & Corrosol fruit (Cameroon) & + \\
\hline 21.4 & Cocoa beans (Cameroon) & - \\
\hline 21.6 & Cocoa beans (Cameroon) & - \\
\hline $21.1 \mathrm{t} 1$ & Cocoa beans (Cameroon) & - \\
\hline
\end{tabular}


Table 1. Cont.

\begin{tabular}{|c|c|c|}
\hline Sensitive Yeast Codes & Isolation Source & Killer Activity \\
\hline Fi6 & Tuscany winery & + \\
\hline Fi10 & Tuscany winery & ++ \\
\hline Fi14 & Tuscany winery & + \\
\hline Fi17 & Tuscany winery & + \\
\hline Fi22 & Tuscany winery & + \\
\hline Fi32 & Tuscany winery & + \\
\hline Fi38 & Tuscany winery & ++ \\
\hline Fi43 & Tuscany winery & $+1-$ \\
\hline 126 & Chianti Wine & + \\
\hline 113 & Chianti Wine & + \\
\hline 129 & Chianti Wine & + \\
\hline 130 & Chianti Wine & $+/-$ \\
\hline 124 & Chianti Wine & $+1-$ \\
\hline $212 c$ & Chianti Wine & + \\
\hline 116 & Chianti Wine & + \\
\hline 34 & Chianti Wine & + \\
\hline 69 & Chianti Wine & - \\
\hline 111 & Chianti Wine & + \\
\hline 107 & Chianti Wine & - \\
\hline 117 & Chianti Wine & - \\
\hline 1189 & Winery (fermentation tank) & + \\
\hline 1194 & Winery (fermentation tank) & ++ \\
\hline 1191 & Winery (fermentation tank) & ++ \\
\hline $212 d$ & Winery (fermentation tank) & + \\
\hline 121 & Winery (fermentation tank) & + \\
\hline 118 & Winery (fermentation tank) & + \\
\hline 106 & Winery (fermentation tank) & $+/-$ \\
\hline 1190 & Winery (fermentation tank) & ++ \\
\hline 94 & Winery (fermentation tank) & - \\
\hline 90 & Winery (fermentation tank) & - \\
\hline G1 & Craft Belgium Gueze beer & + \\
\hline G2 & Craft Belgium Gueze beer & + \\
\hline G3 & Craft Belgium Gueze beer & + \\
\hline G4 & Craft Belgium Gueze beer & + \\
\hline G5 & Craft Belgium Gueze beer & + \\
\hline G6 & Craft Belgium Gueze beer & + \\
\hline G7 & Craft Belgium Gueze beer & + \\
\hline G8 & Craft Belgium Gueze beer & + \\
\hline G9 & Craft Belgium Gueze beer & + \\
\hline G10 & Craft Belgium Gueze beer & + \\
\hline
\end{tabular}




\subsection{Killer Assay}

The killer activity of $W$. anomalus strain 18 was tested against a panel of yeasts by the diffusion plate assay; the plate was seeded with sensitive strain at a final concentration of $10^{6} \mathrm{CFU} \mathrm{mL}{ }^{-1}$ in Malt Agar $\mathrm{pH}$ 4.2. An exponential culture of W. anomalus was spotted, and after $72 \mathrm{~h}$ of incubation at $25^{\circ} \mathrm{C}$, strains were designated as sensitive when the spot grew surrounded by a clear zone of inhibition. The assay was repeated in triplicate. The diameter of the inhibition zone was measured with a caliber. Killer activity (KA) was defined as arbitrary units (AU) per $\mathrm{mL}$ and was calculated considering the diameter of the inhibition zone in millimeters, where $1 \mathrm{AU}$ is the amount of toxin capable of producing a clear inhibition zone of $12 \mathrm{~mm}$ in diameter.

\subsection{Test of the Killer Activity of Strain 18}

To identify the killer activity of $W$. anomalus strain 18 against sensitive $B$. bruxellensis DiSVA 46 and to demonstrate that the mycocin was produced and extracellular secreted, the well-test screening method was performed. An aliquot of B. bruxellensis strain from a YPD agar plate culture was suspended in sterile water until a suspension with OD 600 of 0.1 (approximately $10^{6} \mathrm{CFU} \mathrm{mL}{ }^{-1}$ ) was obtained. Inside the Petri dish, $1 \mathrm{~mL}$ of the microbial suspension was poured and distributed and $20 \mathrm{~mL}$ of Malt Agar at $\mathrm{pH} 4.2$ with $0.1 \mathrm{M}$ citrate-phosphate buffer. Sterile wells with a diameter of $6 \mathrm{~mm}$ were placed on still liquid agar. After solidification, the wells were removed with sterile forceps and each space was filled with $70 \mu \mathrm{L}$ of supernatant filter-sterilized through $0.45 \mu \mathrm{m}$ pore-size filters. The extracellular killer activity was evaluated by measuring the diameter of the zone of inhibition around the wells [21] after incubation at $25^{\circ} \mathrm{C}$ for about five days.

\subsection{Production and Purification of WA18}

To establish the maximum amount of mycocin produced and the corresponding time, $W$. anomalus was cultivated in YPB broth in a 1 L Erlenmeyer flask with a $300 \mathrm{~mL}$ working volume (Table 2). During the microbial growth, samples were taken every $2 \mathrm{~h}$ to evaluate both cell growth and the diameter of inhibition halo. In the purification trials, W. anomalus strain 18 was inoculated at $1 \times 10^{6} \mathrm{CFU} \mathrm{mL} \mathrm{m}^{-1}$ in type A medium broth $\mathrm{pH}$ 4.2 and incubated at $25^{\circ} \mathrm{C}$ for $48 \mathrm{~h}$. The medium contained a limited concentration of glucose to avoid the presence of residual sugars in the concentrated product, which during experiments in wine could represent a nutrition source for sensitive cells. The culture was centrifuged at $14,000 \times g$ for $10 \mathrm{~min}$, and the crude extract obtained was sterilized by filtration with $0.2 \mu \mathrm{m}$ PVDF filters (Millipore).

Table 2. Purification of WA18 from W. anomalus.

\begin{tabular}{|c|c|c|c|c|c|c|c|}
\hline & $\begin{array}{l}\text { Total Volume } \\
\text { (mL) }\end{array}$ & $\begin{array}{c}\text { Total } \\
\text { Protein }(\mathrm{mg})\end{array}$ & $\begin{array}{l}\text { Activity } \\
\left(\text { AU mL } \mathrm{mL}^{-1}\right)\end{array}$ & $\begin{array}{l}\text { Total Activity } \\
\text { (AU) }\end{array}$ & $\begin{array}{l}\text { Specific Activity } \\
\left(\mathrm{AU} \mathrm{mg}^{-1}\right)\end{array}$ & $\begin{array}{l}\text { Purification } \\
\quad \text { (fold) }\end{array}$ & $\begin{array}{c}\text { Yield } \\
(\%)\end{array}$ \\
\hline Culture broth & 5000 & 595 & 1 & 5000 & 8.4 & 1 & 100 \\
\hline $\begin{array}{l}\text { Ultrafiltration } \\
10 \text { kDa cutoff PPCE } \\
\text { (partially purified } \\
\text { crude extract) }\end{array}$ & 50 & 7.45 & 70 & 3500 & 289.3 & 34.44 & 70 \\
\hline $\begin{array}{l}\text { Ionic exchange } \\
\text { chromatography } \\
\text { (SP Sepharose) } \\
\text { 10-fold concentrated }\end{array}$ & 15 & 1.4 & 104 & 1560 & 1114.3 & 132.64 & 31.2 \\
\hline $\begin{array}{c}\text { Second step of } \\
\text { ultrafiltration } 50 \mathrm{kDa} \text { cutoff }\end{array}$ & 8.3 & 0.14 & 27.5 & 228.25 & 1630.36 & 194 & 4.57 \\
\hline
\end{tabular}

For the purification procedures, $5 \mathrm{~L}$ of fermented broth was filter-sterilized $(0.45 \mu \mathrm{m}$ pore size filter) was concentrated by two steps of ultrafiltration: (i) tangential flow in a Bioflex apparatus (Schleicher e Schuell $\mathrm{GmbH}$, Germany) using a membrane with a cutoff of $10.000 \mathrm{Da}$; (ii) ultrafiltration step using cell stirred apparatus (Amicon ${ }^{\circledR}$, Merk, 
Roma, Italy) until a final volume of $50 \mathrm{~mL}$. The sample was subsequently dialyzed into a $14,000 \mathrm{Da}$ cutoff capillary tube in $2 \mathrm{~L}$ of $0.01 \mathrm{M}$ citrate-phosphate buffer at $\mathrm{pH} 4.2$ overnight stirring. This ultra-filtered and dialyzed sample was used for the further characterization of WA18 mycocin.

The PPCE was purified by size exclusion chromatography (Sephadex G-75) through a $1.5 \times 160 \mathrm{~mm}^{2}$ Sephadex G-75 column with $0.1 \mathrm{M}$ citric acid/dibasic sodium phosphate $\mathrm{pH}$ 4.2 at a flow of $0.25 \mathrm{~mL} \mathrm{~min}^{-1}$. Due to unsatisfactory results, the same amount of sample was loaded in ionic exchange chromatography using a strong cationic SP Sepharose fast flow (GE Health Care) matrix set up in a $15 \times 230 \mathrm{~mm}^{2}$ column and using as $\mathrm{NaCl}$ elution buffer in increasing concentrations from 0.1 to $0.5 \mathrm{M}$. The flow was set to $1 \mathrm{~mL} \mathrm{~min}^{-1}$, and $5 \mathrm{~mL}$ volume fractions were collected. The active fractions were combined, dialyzed and undergone a second ultrafiltration treatment using a membrane with $50 \mathrm{kDa}$ cutoff. During the purification procedure, the killer activity of fractions and relative protein concentration was quantified by a well-test assay and the Bradford procedure for protein evaluation [22]. Purified WA18 fraction was subsequently analyzed by sodium dodecyl sulfate-polyacrylamide gel electrophoresis (SDS-PAGE) using silver staining technique [23].

\subsection{Binding of WA18 by Cell-Wall Polysaccharides}

The sensitive B. bruxellensis type strain DiSVA $46\left(10^{5} \mathrm{CFU} \mathrm{mL}^{-1}\right)$ was treated with the mycocin $\left(70 \mathrm{AU} \mathrm{mL} \mathrm{m}^{-1}\right)$ in the absence or presence of $9 \mathrm{mg} \mathrm{mL}^{-1}$ of the following cell-wall polysaccharides: laminarin (Sigma-Aldrich, Saint Louis, MO, USA), mannan (Sigma-Aldrich, Saint Louis, MO, USA), glucan (Sigma-Aldrich, Saint Louis, MO, USA) and pustulan (Calbiochem). After incubation at $20^{\circ} \mathrm{C}$ for $24 \mathrm{~h}$, the cell samples were subjected to a well test to quickly observe the inhibition and to viable cell counts to assess the binding activities of the polysaccharides.

\subsection{WA18 Sequencing}

A high-resolution LC-MS analysis was performed on the purified fraction to obtain the accurate molecular weight of the protein. Subsequently, digestion with two restriction enzymes (Lis-C, lysine cutoff site (K) and trypsin; lysine (K) and arginine (R) cut sites, was carried out (Sigma-Aldrich, USA). The LC-MS and LC-MS/MS analysis of the two enzymatic digests obtained will be carried out to obtain the high-resolution fragmentation spectra related to the peptides.

The bioinformatics processing of the fragmentation spectra related to the peptides obtained from the two triplex digestions was elaborated by means of different research approaches in the NCBI database and of number sequencing to maximize the statistical accuracy parameters related to the identification of the sequences.

\subsection{Protease Treatment}

WA18 purified proteins were subjected to protease treatments. Five hundred microliters of purified toxin $\left(0.017 \mathrm{mg} \mathrm{mL}^{-1}\right)$ were mixed with $125 \mu \mathrm{L}$ of each of the following proteases: trypsin, papain, proteases XIV and XVIII, and pepsin $\left(10 \mathrm{mg} \mathrm{mL}^{-1}\right)$ and incubated at $25^{\circ} \mathrm{C}$ for $24 \mathrm{~h}$ and/or $72 \mathrm{~h}$, as previously described by Comitini et al. [22]. The residual killer activities were evaluated by means of the well-plate assay as described above.

\subsection{Stability of WA18}

For mycocin stability assays, the $\mathrm{pH}$ and temperature of two identical PPCE lots (70 AU mL ${ }^{-1}$ ) already produced and with tested inhibition halo of $30 \mathrm{~mm}$ were modified for $\mathrm{pH}$ and temperature values and tested after $1.30 \mathrm{~h}$. In particular, $\mathrm{pH}$ ranges from 2.5 to 5.75 adjusted with $1 \mathrm{M} \mathrm{HCl}$ or $1 \mathrm{M} \mathrm{NaOH}$ (with intervals of $0.25 \mathrm{pH}$ points), and temperature intervals from 10 to $75^{\circ} \mathrm{C}$ (with intervals of $5{ }^{\circ} \mathrm{C}$ ) were assayed, respectively. After each treatment, residual killer activity was measured by the well-test method in the plate, comparing the obtained results with untreated PPCE. The reduction was calculated as the percentage of discrepancy in diameter halos from optimal $\mathrm{pH}$ and temperature conditions. 
2.9. Evaluation of Fungicide Activity of PPCE WA18 against Brettanomyces bruxellensis Strains in Wine

The effective antimicrobial activity of WA18 toward B. bruxellensis strains, which can occur in wine, was evaluated. The main characters of wine were: $\mathrm{SO}_{2}$ free; $\mathrm{pH}$ 3.5; ethanol $10 \% \mathrm{v} / \mathrm{v}$. Preliminary, $70 \mathrm{~mL}$ of natural red must in $100 \mathrm{~mL}$ flask supplemented with $10 \mathrm{mg} \mathrm{L}^{-1}$ of p-cumaric acid was inoculated with $1 \times 10^{5} \mathrm{CFU} \mathrm{mL}^{-1}$ of 17 different $B$. bruxellensis strains (previously isolated from contaminated wine) and incubated at $25{ }^{\circ} \mathrm{C}$ for five months. After this time, only the Brettanomyces strains that survived with cell concentrations greater than or equal to $1 \times 10^{4} \mathrm{CFU} \mathrm{mL}{ }^{-1}$ were selected. Among them, the B. bruxellensis viable cell concentration of final wine was standardized at $3.5 \times 10^{3} \mathrm{CFU} \mathrm{mL}^{-1}$ using a natural wine $\mathrm{SO}_{2}$ free and transferred in tubed of $10 \mathrm{~mL}$ containing $9 \mathrm{~mL}$, with or without $100 \mu \mathrm{L}$ of PPCE of WA18 (70 of AU mL $\left.{ }^{-1}\right)$. The vitality of B. bruxellensis potential sensitive strain was evaluated periodically within the first 60 days by viable cell counts (data not shown). After 60 days, wine samples were evaluated for the ethyl phenol and ethyl guaiacol concentration by the solid-phase microextraction (HS-SPME method following the protocol described by Canonico et al. [24].

\subsection{Co-Culture of W. anomalus 18 with $S$. cerevisiae Strains}

W. anomalus pure and mixed cultures (W. anomalus $18 /$ S. cerevisiae commercial starters QA23, BC, BM45, EC1118 (Lalvin, D\&C wine) were set up to exclude the negative influence of killer strain on alcoholic fermentation of some most diffused starter strains. Flasks containing $70 \mathrm{~mL}$ of pasteurized commercial red must were aseptically inoculated with the different $S$. cerevisiae cultures to obtain an initial cell density of $5 \times 10^{6} \mathrm{CFU} \mathrm{mL} \mathrm{md}^{-1}$ and $1 \times 10^{6} \mathrm{CFU} \mathrm{mL} \mathrm{mL}^{-1}$ of $W$. anomalus strain 18 (mixed culture). Microfermentations were incubated at $16{ }^{\circ} \mathrm{C}$ for 10 days. Enumeration of $W$. anomalus was carried out in Lysin medium since $S$. cerevisiae is not capable of growing in this medium, whereas total yeast count was performed in YPD medium.

\section{Results}

\subsection{Anti-Brettanomyces Spectrum}

To assay, the anti-Brettanomyces spectrum and the effectiveness of the mycocin of $W$. anomalus $18, B$. bruxellensis strains coming from different sources such as grapes, winery or beer were used. W. anomalus strain 18 was able to inhibit 62 out of 75 B. bruxellensis strains assayed (83\%), of which 10 strains were strongly inhibited while 7 strains were only slightly inhibited, as shown in Table 1.

\subsection{Characterization of WA18}

To further understand the nature of WA18, the production of mycocin was relatively quantified by assigning arbitrary units (AU) monitored during the batch cultivation of the producing strains by means of the well-plate assay (Table 2). In this case, B. bruxellensis DiSVA 46 was used as a sensitive strain. Results showed that the production of WA18 mycocin started after $16 \mathrm{~h}$ of incubation (beginning of the exponential growth phase) when a visible inhibition halo around the well appeared (Figure 1). Well tests revealed a constant increase in toxin production during exponential growth with a peak during the early stationary phase, until the $32 \mathrm{nd} \mathrm{h}$. However, WA18 production was highest and stable between the $22 \mathrm{nd}$ and the $26 \mathrm{th} \mathrm{h}(\varnothing$ halo $=20 \mathrm{~mm})$. 


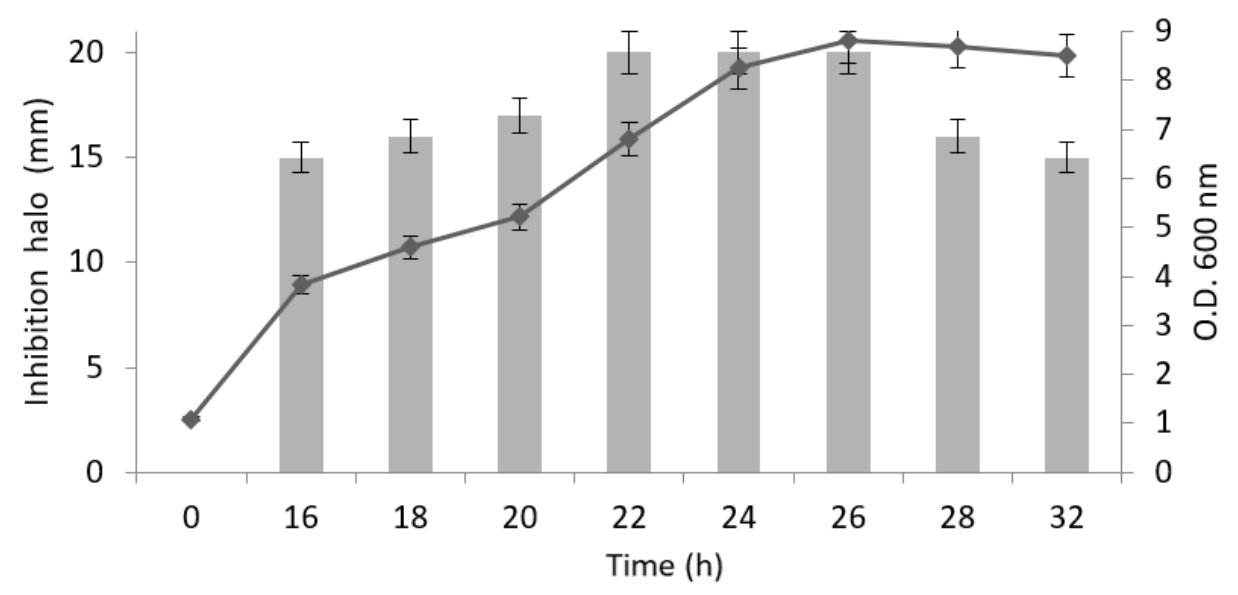

Figure 1. Correlation between $W$. anomalus strain 18 growth evaluated by measuring optical density O.D. $600 \mathrm{~nm}$ (line) and production of mycocin (bars) expressed as the diameter of the halo produced against sensitive strain B. bruxellensis DiSVA 46. Results were obtained from two experiments carried out separately, and relative standard errors were added.

The killer activity was present at a $\mathrm{pH}$ range from 3.25 to 4.50 with pronounced activity at $\mathrm{pH}$ 4.00. The highest killer activity was observed at $20^{\circ} \mathrm{C}$ temperature and $4.20 \mathrm{pH}$ value (Table 3).

Regarding thermostability, the toxin was stable until $25^{\circ} \mathrm{C}$ with a lost $10 \%$ of activity starting from $30^{\circ} \mathrm{C}$ (after $1 \mathrm{~h}$ and half of the incubation) (Table 3 ). To confirm the proteinaceous nature of WA18, the mycocin was subjected to protease treatments. As expected, the WA18 was sensitive to proteolytic enzymes used, thus confirming the proteinaceous nature of mycocin (data not shown).

With the aim of identifying the first receptor site of WA18 on the envelope of sensitive cells, the competitive inhibition of mycocin by cell-wall polysaccharides was investigated using mannan, laminarin (mainly $\beta-1,3-$, with a few $\beta$-1,6-linked glucans), pustulan $(\beta-1,6-$ glucan) and glucan ( $\beta-1,3-$ and $\beta-1,6$-branched glucans). The results show that only glucans were able to competitively inhibit killing action and enhance cell survival. In contrast, mannan, laminarin and pustulan could not rescue the cells, possibly due to their inability to bind WA18 (Table 4).

Table 3. Influence of $\mathrm{pH}$ and temperature on WA18 killer activity.

\begin{tabular}{cccc}
\hline $\mathbf{p H}$ & $\begin{array}{c}\text { WA18 Killer Activity } \\
\text { Reduction }\end{array}$ & Temperature $\left({ }^{\circ} \mathbf{C}\right)$ & $\begin{array}{c}\text { WA18 Killer Activity } \\
\text { Reduction * }\end{array}$ \\
\hline 2.50$)$
\end{tabular}

* 100 represents the optimal values. 
Table 4. Evaluation of WA18 killer activity after binding by cell-wall polysaccharides by well test assay against sensitive strain B. bruxellensis DiSVA 46.

\begin{tabular}{|c|c|c|}
\hline Cell-Wall Polysaccharides & & \\
\hline Laminarin (L) & 27 & 2 \\
\hline Pustulan (P) & 26 & (2) \\
\hline Mannans (M) & 28 & (2) \\
\hline Glucans (G) & 0 & \\
\hline WA18 crude extract $(+)$ & 30 & (4) \\
\hline
\end{tabular}

\subsection{Production and Purification of WA18}

W. anomalus strain 18 was grown in type A medium for $28 \mathrm{~h}$ at $20^{\circ} \mathrm{C}$. The broth was then filtered and concentrated to a final volume of approximately $50 \mathrm{~mL}$ reaching a $100 \times$ concentrate (PPCE). Due to unsatisfactory results, after several attempts (gel filtration and different ionic exchange matrix), the PPCE was loaded in an SP-Sephadex ionic exchange chromatography (strongly cationic matrix) that revealed the presence of a major peak corresponding to the unbound fraction eluted without salt. The elution with increased concentration of $\mathrm{NaCl}$ allowed to separate WA18 mycocin in three fractions where the $280 \mathrm{~nm}$ absorbance was higher, the well test showed distinctive inhibition halos, and the relative protein concentration were $67.18,71.82$ and $38.52 \mathrm{mg} \mathrm{L}^{-1}$ in fractions \#36, \#37 and \#38, respectively (data not shown). After being tested the positive three fractions separately, they were pooled and loaded on polyacrylamide gel (Figure 3) to observe the corresponding protein bands (Figure 2).

The gel showed the presence of two high molecular weight bands (greater than $72 \mathrm{kDa}$ ) and another around $30 \mathrm{kDa}$. This required a further step before reaching purification; the pool of three active fractions was subjected to a second ultrafiltration step (membrane with cutoff $50 \mathrm{kDa}$ ) in which the filtrate (molecular weight less than $50 \mathrm{kDa}$ ) was separated from the retentate (molecular weight greater than $50 \mathrm{kDa}$ ).

The purification of protein was confirmed by SDS-Page that revealed the presence of a single band with an apparent molecular weight of about $31 \mathrm{kDa}$ (Figure 3). Biochemical steps carried out to purify WA18 killer toxin allowed to obtain a purification yield of about $5 \%$ (with 194 purification fold) in a final $500 \mu \mathrm{l}$ fraction with $27.5 \mathrm{AU} \mathrm{mL}^{-1}$, corresponding to $0.017 \mathrm{mg} \mathrm{mL}^{-1}$ of protein (Table 2). 


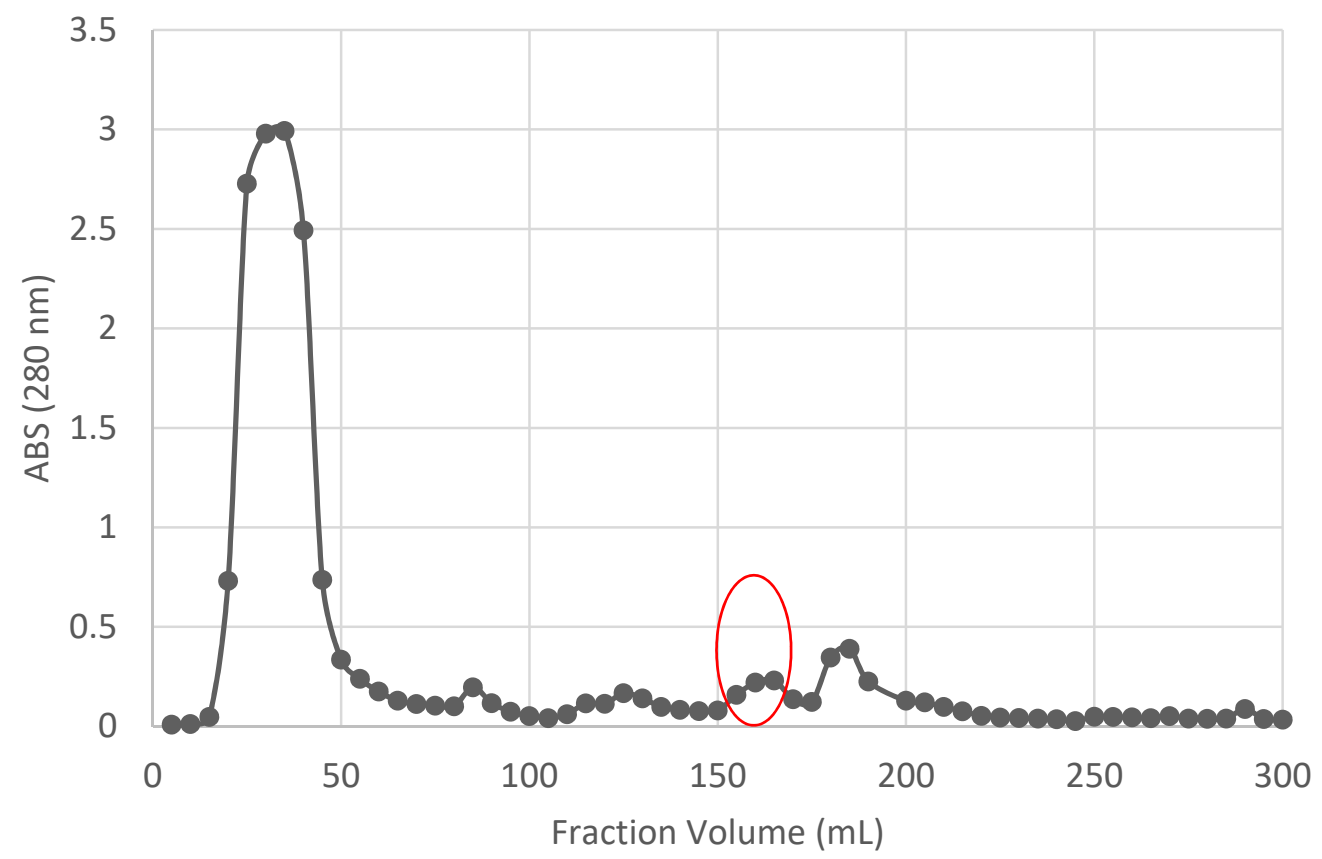

Figure 2. Fractions eluted using SP Sepharose-cation exchange chromatography. Circled peak corresponds to the active fractions (with killer activity).

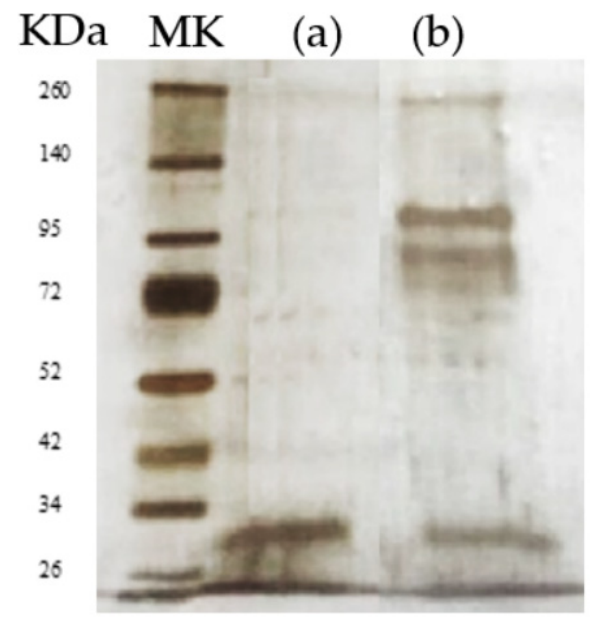

Figure 3. SDS Page of purified WA18 mycocin. MK marker; (a) purified fraction; (b) SP Sepharosecation exchange chromatography active fractions.

The sequencing analysis of purified WA18 (visualized in a single pick after 11 min of chromatography) showed no match with known proteins, using generic databases (Protein Blast NCBI Library), as reported in Figure 4. The peptide sequences detected by the DeNovo approach and selected for statistical accuracy were able to provide important information after a Blast analysis for homology. Sequences due to trypsin fragments and other contaminants were filtered and excluded. The most probable candidate has a primary structure analogous to the UDP-glycosyltransferase protein, also confirming the molecular weight. 


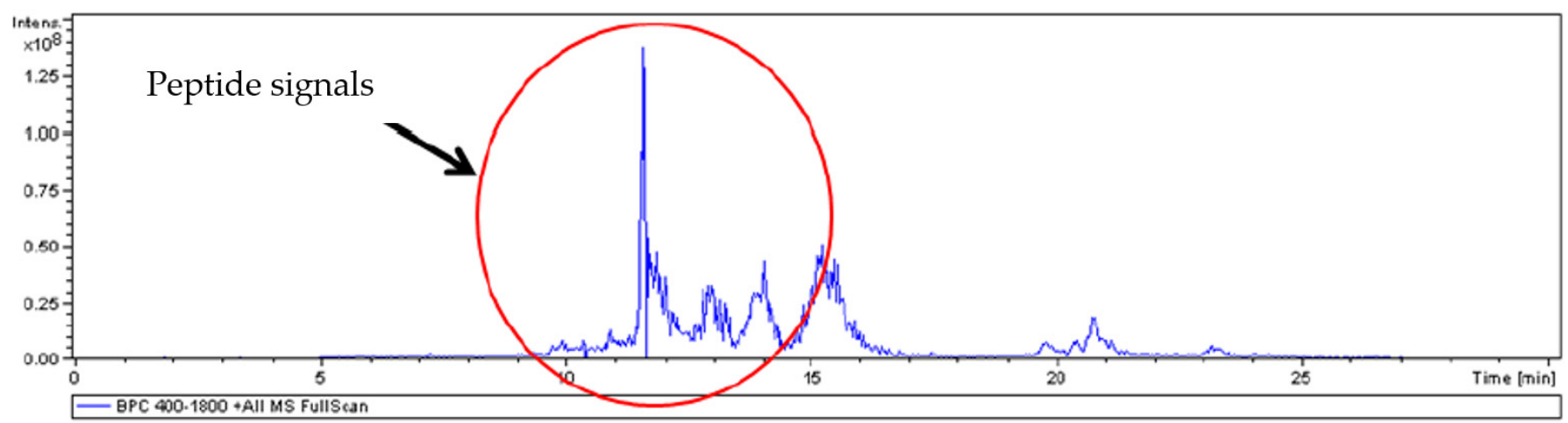

Figure 4. Signal peptide analysis graphic of consensus amino acid sequence of digested WA18 purified mycocin.

\subsection{Effect of WA18 in Wine}

In order to evaluate WA18 antimicrobial properties related to its potential use in winemaking, the antagonistic activity against $B$. bruxellensis strains in wine was investigated. WA18 mycocin (PPCE, AU mL ${ }^{-1}$ ) was tested in wine in which 9 different B. bruxellensis strains (the only survivors after five months in wine) were inoculated in sterile must and grown for 5 months. Wines treated with PPCE WA18 mycocin /700 AU L ${ }^{-1}$ exhibited only a slight increase of phenols concentration after 60 days, around 5\%, with the only exception of $212-C$ strain that showed a large increase of $22.6 \%$ and $66.7 \%$ of 4 ethyl phenol and 4 ethyl guaiacol, respectively (Table 5). Differently, without the mycocin, a large enhancement of 4 ethyl guaiacol was found; the trends of 4 ethyl phenol were variable and strongly linked to the strain considered. Indeed, in relation to the strains of B. bruxellensis 10-B, 14-A, 219A, $25-B$ and $212-C$, the increase varied from a minimum of $24 \%$ to a maximum of about $880 \%$ of the initial concentration of ethyl phenols.

Table 5. Effect of WA18 mycocin using partially concentrated crude extract (AU $700 \mathrm{~L}^{-1}$ in the wine samples) on ethyl phenol and ethyl guaiacol production by different B. bruxellensis strains after 60 days of incubation.

\begin{tabular}{|c|c|c|c|c|c|c|c|c|c|c|c|c|c|c|}
\hline \multirow{2}{*}{$\begin{array}{l}\text { Sensitive } \\
\text { Strains }\end{array}$} & \multicolumn{7}{|c|}{4 Ethyl Phenol ( $\mu \mathrm{g} / \mathrm{L})$} & \multicolumn{7}{|c|}{4 Ethyl Guaiacol $(\mu \mathrm{g} / \mathrm{L})$} \\
\hline & Initial & $\begin{array}{l}\text { w/o } \\
\text { WA18 }\end{array}$ & $\begin{array}{c}\Delta(\text { w/o } \\
\text { WA18-initial })\end{array}$ & $\Delta \%$ & WA18 & $\begin{array}{c}\Delta \text { (WA18- } \\
\text { initial) }\end{array}$ & $\Delta \%$ & Initial & $\begin{array}{l}\text { w/o } \\
\text { WA18 }\end{array}$ & $\begin{array}{c}\Delta(w / o \\
\text { WA18-initial) }\end{array}$ & $\Delta \%$ & WA18 & $\begin{array}{c}\Delta \text { (WA18- } \\
\text { initial) }\end{array}$ & $\Delta \%$ \\
\hline $10-B$ & 593 & 739 & 146 & 24.62 & 633 & 40 & 6.75 & 58 & 146 & 88 & 151.72 & 70 & 12 & 20.69 \\
\hline $14-\mathrm{A}$ & 368 & 876 & 508 & 138.04 & 399 & 31 & 8.42 & 44 & 212 & 168 & 381.82 & 47 & 3 & 6.82 \\
\hline 219A & 410 & 626 & 216 & 52.68 & 421 & 11 & 2.68 & 59 & 99 & 40 & 67.80 & 64 & 5 & 8.47 \\
\hline $25-\mathrm{B}$ & 99 & 972 & 873 & 881.82 & 100 & 1 & 1.01 & 105 & 222 & 117 & 111.43 & 109 & 4 & 3.81 \\
\hline $212-C$ & 531 & 886 & 355 & 66.85 & 651 & 120 & 22.60 & 21 & 195 & 174 & 828.57 & 35 & 14 & 66.67 \\
\hline DiSVA 48 & 517 & 532 & 15 & 2.90 & 554 & 37 & 7.16 & 10 & 101 & 91 & 910.00 & 10 & 0 & 0.00 \\
\hline 21.6 & 601 & 619 & 18 & 3.00 & 606 & 5 & 0.83 & 19 & 131 & 112 & 589.47 & 24 & 5 & 26.32 \\
\hline 1191 & 520 & 526 & 6 & 1.15 & 519 & -1 & -0.19 & 29 & 116 & 87 & 300.00 & 32 & 3 & 10.34 \\
\hline $5-6 \mathrm{~A}$ & 421 & 430 & 9 & 2.14 & 463 & 42 & 9.98 & 65 & 103 & 38 & 58.46 & 63 & -2 & -3.08 \\
\hline
\end{tabular}

The initial values are referred to as ethyl phenols concentration after 5 months of fermentation of a sterile red grape must be inoculated with each strain. $\Delta$ and $\Delta \%$ symbols indicate the differences in ethyl phenols content concentration between initial and after 60 days, with and without (w/o) WA18 mycocin.

\section{Discussion}

The application of emerging technologies based on the use of bioactive microorganisms for food and beverages microbial control and preservation is a relevant topic in the wine industry $[25,26]$. This natural approach can be highly efficient in reducing the growth of spoilage microorganisms as well as the production of undesirable microbial metabolites during processing. As a direct consequence of the proper use of bioactive yeasts, oenologists can easily manage fermentation. Moreover, the production of undesired compounds can be controlled, and the quality of wine can be improved by reducing the use of chemical compounds.

In this work, it was investigated a new mycocin WA18 produced by $W$. anomalus. This killer yeast was isolated in a natural underground pit used for maturing cheeses, a habitat 
at low-temperature $\left(<12{ }^{\circ} \mathrm{C}\right)$, at a high relative humidity $(<70 \%)$ and at high concentrations of $\mathrm{CO}_{2}$ (reduced environment) [20]. Probably the extreme environmental conditions to which this yeast has adapted made WA18 mycocin able to resists under winemaking conditions. The wide spectrum of activity showed by WA18 toward B. bruxellensis strains is in agreement with the inhibitory spectrum showed by other investigated strains of $W$. anomalus toward B. bruxellensis, described in the literature $[22,27,28]$. Regarding the main biochemical characteristics, WA18 showed an apparent molecular weight of about $31 \mathrm{kDa}$ and exhibited an identity with a glycosyltransferase protein, while glucans were the receptor sites of the cell wall. These results showed some similarities and several differences with the other $W$. anomalus characterized mycocins. Indeed, Pikt from $W$. anomalus showed a ubiquitin-like peptide structure with a molecular mass of approximately $8 \mathrm{kDa}$ and that it selectively interacts with $\beta-1,6$ glucans [29] while the mycocin KTCf20 secreted by the strain $W$. anomalus $\mathrm{Cf} 20$ bind to $\beta-1,3$ and $\beta-1,6$ glucans of the cell wall of sensitive strains [13]. Moreover, the results of the thermostability and $\mathrm{pH}$ range of activity of WA18 were very similar to other mycocins produced by $W$. anomalus, which showed activity and stability at acidic $\mathrm{pH}(2-4.5)$ and temperature lower than $35^{\circ} \mathrm{C}[7,13,22,30]$.

Regarding the biochemical purification process allowed to purify WA18 mycocin, the approach used here (ultrafiltration, ion-exchange chromatography and double ultrafiltration steps using different cutoff membranes) was also applied by Villalba et al. [31] during Saccharomyces eubayanus mycocin (SeKT) purification but using affinity chromatography with pustulans as a pre-purification strategy. On the contrary, de Ullivarri et al. [13] carried out toxin with only one-step of ultrafiltration by using $50 \mathrm{kDa}$ membrane and exclusion chromatography.

Furthermore, the in vitro binding affinity test to cell wall polysaccharides revealed that WA18 mycocin binds branched glucans on the cell wall of sensitive yeasts. The binding to these types of polysaccharides also has been widely reported [12,13,32]. In addition, the thermo-sensitivity of WA18 is similar to other studied $W$. anomalus yeast toxins $[7,12,33]$.

WA18 purified chromatography fraction was subjected to LC-MS/MS analysis, and results allowed a BLAST-p identification as the primary sequence of UDP-glycosyltransferase protein. In addition, Cecarini et al. [34] performed the same analysis for $140 \mathrm{kDa}$ WaF17.12 mycocin produced by $W$. anomalous detected five peptide fractions described as the $\beta$ glucosidase enzyme.

From the applied point of view, the null effect of this mycocin against $S$. cerevisiae starter strains tested, represent a positive opportunity for its use in mixed culture, during industrial processes. Furthermore, the antimicrobial activity trials carried out in wine with a WA18 concentration of $700 \mathrm{UA} \mathrm{L}^{-1}$ showed that the toxin was able to control the growth of B. bruxellensis strains and its production of ethyl phenols. Similar to SeKT from S. eubayanus [31], WA18 mycocin reduced the levels of volatile phenols produced by $B$. bruxellensis strains after the time of evaluation of 60 days, showing a reduction of about 10 -fold in comparison with samples without the presence of mycocin.

Based on traditional knowledge as well as recent scientific evidence, killer yeasts are one of the most important players in food biotechnology to control Brettanomyces yeast in winemaking. Indeed, Brettanomyces/Dekkera spoilage yeasts affect the wine marketability for red and white wines and also for the sparkling industry [11,35].

In this context, the mycocin WA18 could have good potential as a biocontrol agent active against Brettanomyces spp. since the broad-spectrum of activity is shown.

Author Contributions: F.C. and M.C. validated the overall results and supervised the manuscript. A.A. carried out the practical experiments in the laboratory, and L.C. and E.G. managed the processing of the results. All authors have read and agreed to the published version of the manuscript.

Funding: This research received no external funding.

Data Availability Statement: Data is contained within the article.

Conflicts of Interest: The authors do not have financial and/or personal conflicts of interest regarding the study reported in the present manuscript. 


\section{References}

1. Liu, G.L.; Chi, Z.; Wang, G.Y.; Wang, Z.P.; Li, Y.; Chi, Z.M. Yeast killer toxins, molecular mechanisms of their action and their applications. Crit. Rev. Biotechnol. 2015, 35, 222-234. [CrossRef] [PubMed]

2. São-José, C.; Santos, M.A.; Schmitt, M.J. Viruses of wine-associated yeasts and bacteria. In Biology of Microorganisms on Grapes, in Must and in Wine; Springer: Cham, Switzerland, 2017; pp. 133-154.

3. Klassen, R.; Schaffrath, R.; Buzzini, P.; Ganter, P.F. Antagonistic interactions and killer yeasts. In Yeasts in Natural Ecosystems: Ecology; Springer: Cham, Switzerland, 2017; pp. 229-275.

4. Schaffrath, R.; Meinhardt, F.; Klassen, R. Yeast killer toxins: Fundamentals and applications. In Physiology and Genetics; Springer: Cham, Switzerland, 2018; pp. 87-118.

5. Mannazzu, I.; Domizio, P.; Carboni, G.; Zara, S.; Zara, G.; Comitini, F.; Budroni, M.; Ciani, M. Yeast killer toxins: From ecological significance to application. Crit. Rev. Biotechnol. 2019, 39, 603-617. [CrossRef] [PubMed]

6. Hatoum, R.; Labrie, S.; Fliss, I. Antimicrobial and probiotic properties of yeasts: From fundamental to novel applications. Front. Microbiol. 2012, 3, 421. [CrossRef] [PubMed]

7. Muccilli, S.; Restuccia, C. Bioprotective Role of Yeasts. Microorganisms 2015, 3, 588-611. [CrossRef]

8. Kurtzman, C.P.; Fell, J.W. The Yeasts, a Taxonomic Study, 4th ed.; Elsevier: Amsterdam, The Netherlands, 1998; Volume 2, pp. 77-102.

9. Padilla, B.; Zulian, L.; Ferreres, À.; Pastor, R.; Esteve-Zarzoso, B.; Beltran, G.; Mas, A. Sequential inoculation of native nonSaccharomyces and Saccharomyces cerevisiae strains for wine making. Front. Microbiol. 2017, 8, 1293. [CrossRef] [PubMed]

10. Ciani, M.; Comitini, F. Non-Saccharomyces wine yeasts have a promising role in biotechnological approaches to winemaking. Ann. Microbiol. 2011, 61, 25-32. [CrossRef]

11. Berbegal, C.; Spano, G.; Fragasso, M.; Grieco, F.; Russo, P.; Capozzi, V. Starter cultures as biocontrol strategy to prevent Brettanomyces bruxellensis proliferation in wine. Appl. Microbiol. Biotechnol. 2018, 102, 569-576. [CrossRef]

12. İzgü, F.; Altınbay, D.; Türeli, A.E. In vitro activity of panomycocin, a novel exo- $\beta-1,3$-glucanase isolated from Pichia anomala NCYC 434, against dermatophytes. Mycoses 2007, 50, 31-34. [CrossRef]

13. de Ullivarri, M.F.; Mendoza, L.M.; Raya, R.R. Characterization of the killer toxin KTCf20 from Wickerhamomyces anomalus, a potential biocontrol agent against wine spoilage yeasts. Biol. Control 2018, 121, 223-228. [CrossRef]

14. Druvefors, Ä.U.; Schnürer, J. Mold-inhibitory activity of different yeast species during airtight storage of wheat grain. FEMS Yeast Res. 2005, 5, 373-378. [CrossRef]

15. Jijakli, M.H. Pichia anomala in biocontrol for apples: 20 years of fundamental research and practical applications. Antonie Van Leeuwenhoek 2011, 99, 93-105.

16. Korpi, A.; Järnberg, J.; Pasanen, A.L. Microbial volatile organic compounds. Crit. Rev. Toxicol. 2009, 39, 139-193. [CrossRef] [PubMed]

17. Oro, L.; Feliziani, E.; Ciani, M.; Romanazzi, G.; Comitini, F. Volatile organic compounds from Wickerhamomyces anomalus, Metschnikowia pulcherrima and Saccharomyces cerevisiae inhibit growth of decay causing fungi and control postharvest diseases of strawberries. Int. J. Food Microbiol. 2018, 265, 18-22. [CrossRef] [PubMed]

18. Varela, C.; Borneman, A.R. Yeasts found in vineyards and wineries. Yeast 2017, 34, 111-128. [CrossRef] [PubMed]

19. Oro, L.; Canonico, L.; Marinelli, V.; Ciani, M.; Comitini, F. Occurrence of Brettanomyces bruxellensis on Grape Berries and in Related Winemaking Cellar. Front. Microbiol. 2019, 10, 415. [CrossRef]

20. Biagiotti, C.; Ciani, M.; Canonico, L.; Comitini, F. Occurrence and involvement of yeast biota in ripening of Italian Fossa cheese. Eur. Food Res. Technol. 2018, 244, 1921-1931. [CrossRef]

21. Woods, D.R.; Bevan, E.A. Studies on the nature of the killer factor produced by Saccharomyces cerevisiae. Microbiology 1968, 51, 115-126. [CrossRef]

22. Comitini, F.; Ingeniis De, J.; Pepe, L.; Mannazzu, I.; Ciani, M. Pichia anomala and Kluyveromyces wickerhamii killer toxins as new tools against Dekkera/Brettanomyces spoilage yeasts. FEMS Microbiol. Lett. 2004, 238, 235-240. [CrossRef]

23. Chevallet, M.; Luche, S.; Rabilloud, T. Silver staining of proteins in polyacrylamide gels. Nat. Protocols 2006, 1, 1852. [CrossRef]

24. Canonico, L.; Galli, E.; Ciani, E.; Comitini, F.; Ciani, M. Exploitation of Three Non-Conventional Yeast Species in the Brewing Process. Microorganisms 2019, 7, 11. [CrossRef]

25. Rai, A.K.; Pandey, A.; Sahoo, D. Biotechnological potential of yeasts in functional food industry. Trends Food Sci. Technol. 2019, 83, 129-137. [CrossRef]

26. Vejarano, R.; Gil-Calderón, A.; Díaz-Silva, V.; León-Vargas, J. Improvement of the bioactive profile in wines and its incidence on human health: Technological strategies. In Advances in Grape and Wine Biotechnology; IntechOpen: London, UK, 2019.

27. Comitini, F.; Ciani, M. Kluyveromyces wickerhamii killer toxin: Purification and activity towards Brettanomyces/Dekkera yeasts in grape must. FEMS Microbiol. Lett. 2011, 316, 77-82. [CrossRef] [PubMed]

28. Parafati, L.; Vitale, A.; Restuccia, C.; Cirvilleri, G. Biocontrol ability and action mechanism of food-isolated yeast strains against Botrytis cinerea causing post-harvest bunch rot of table grape. Food Microbiol. 2015, 47, 85-92. [CrossRef]

29. De Ingeniis, J.; Raffaelli, N.; Ciani, M.; Mannazzu, I. Pichia anomala DBVPG 3003 secretes a ubiquitin-like protein that has antimicrobial activity. Appl. Environ. Microbiol. 2009, 75, 1129-1134. [CrossRef] [PubMed]

30. Kagiyama, S.; Aiba, T.; Kadowaki, K.; Mogi, K. New killer toxins of halophilic Hansenula anomala. Agric. Biol. Chem. 1988, 52, 1-7. [CrossRef] 
31. Villalba, M.L.; Mazzucco, M.B.; Lopes, C.A.; Ganga, M.A.; Sangorrín, M.P. Purification and characterization of Saccharomyces eubayanus killer toxin: Biocontrol effectiveness against wine spoilage yeasts. Int. J. Food Microbiol. 2020, 108714. [CrossRef]

32. Magliani, W.; Conti, S.; Gerloni, M.; Bertolotti, D.; Polonelli, L. Yeast killer systems. Clin. Microbiol. Rev. 1997, 10, 369-400. [CrossRef]

33. Mehlomakulu, N.N.; Setati, M.E.; Divol, B. Characterization of novel killer toxins secreted by wine-related non-Saccharomyces yeasts and their action on Brettanomyces spp. Int. J. Food Microbiol. 2014, 188, 83-91. [CrossRef]

34. Cecarini, V.; Cuccioloni, M.; Bonfili, L.; Ricciutelli, M.; Valzano, M.; Cappelli, A.; Amantini, C.; Favia, G.; Eleuteri, A.M.; Angeletti, M.; et al. Identification of a Killer Toxin from Wickerhamomyces anomalus with $\beta$-Glucanase Activity. Toxins 2019, 11, 568. [CrossRef]

35. Smith, B.D.; Divol, B. Brettanomyces bruxellensis, a survivalist prepared for the wine apocalypse and other beverages. Food Microbiol. 2016, 59, 161-175. [CrossRef] 